\title{
The appropriateness of health education
}

\section{La conveniencia de la educación para la salud}

Ariadnne Rionda Arjona ${ }^{a}$

\begin{abstract}
:
The subject of the present dissertation is to emphasize the importance of promoting and using Health Education Theory and strategies, as an advance that manages to overcome the models that are implemented within patient care, through traditional methods; which focus on diseases, their prevention, and treatments if they are present, giving priority to research to care for diseases, thus only fighting against morbid processes, which have already manifested themselves, from the level prevention or care. Health Education is a strategy established in Ottawa, Canada in 1986, at the First World Conference on Health Promotion, which is defined as the process that provides individuals and communities with the means necessary to exercise greater control over their health and thus be able to improve it, with its motto "Health for all in the year 2000"; which has remained a utopian ideal at this time and still implies a challenge for the new century and the changes in the comprehensive health approach.
\end{abstract}

\section{Keywords:}

Health Education, Illness, Levels of Care, Interdisciplinary work.

\section{Resumen:}

El objetivo de la presente disertación es enfatizar la importancia de propiciar y utilizar la Teoría y estrategias de la Educación para la Salud, como un avance que logre superar los modelos que se utilizan dentro de la atención a los pacientes, mediante métodos tradicionales; los cuales se centran en las enfermedades, su prevención y tratamientos en el caso de estar presentes, dando prioridad a la investigación para la atención a las enfermedades, con lo que solo se lucha contra los procesos mórbidos, que ya se han manifestado, desde el nivel de prevención o atención. Por su parte, la Educación para la Salud es una estrategia establecida en Ottawa, Canadá en 1986, en la Primera Conferencia Mundial sobre Promoción de la Salud, donde se la define como: el proceso que proporciona a los individuos y las comunidades los medios necesarios para ejercer un mayor control sobre su propia salud y así poder mejorarla, con su lema "Salud para todos en el año 2000"; el cual ha quedado como un ideal utópico en este momento e implica aún un reto para el nuevo siglo y los cambios en el abordaje de la salud integral.

\section{Palabras Clave:}

Educación para la Salud, Enfermedad, Niveles de atención, Trabajo interdisciplinario.

\section{INTRODUCTION}

First of all, it is worth considering that the concept of health has evolved many years ago, and in recent times it is considered that has advanced. However, many years ago, China had an interesting custom, which consisted of paying to the doctors while they help people keep good health, in other words, provided the person was healthy, but the salary was canceled at the moment that the person was sick, that implies that the doctor could only charge if he maintained a good state of health of a person.

Thus, Traditional Chinese Medicine is holistic since it comprehends that there are no diseases instead sick people. Taking into consideration that diseases do not only happen in the organ, but they are the result of everything that happens in the body, and this is just a way to manifest as an answer to the external factors and the environmental stimuli (Reyes \& Ariel, 2008). On this basis, the health professionals would prefer to look for ways so their patients could be healthy and they did not wish that the person was sick, to keep receiving their salary. On one side, there is an interesting factor to consider in this conception is that the doctor does not heal or cure the patient, instead of that, the body itself does it. Due to the doctors were educators and when they use any type of therapeutical method it was to restore the balance in the patient, even though, it required the participation of the last one through changes and practices that would promote it. (Ardilla, 2015).

On the other side, according to World Health Organization (WHO, 2006, p.1), "the health is a complete state of physical, mental, and social well-being, that it is not only the absence of affections or diseases", that implies a challenge for all those professionals that are part of this sector.

${ }^{a}$ Corresponding author, PhD in Psychology ,https://orcid.org/0000-0002-3600-3479, Email: rionda_ariadnne@ @otmail.com. 
Nevertheless in modern medicine, the disease is conceived as the result of an attack of organisms or external elements and tears on the body because of the time, and bad habits, whereby, the professional practice of the doctor, together with the growing pharmaceutic industry has caused that the research focuses on curing or restoring health rather than looking its maintenance and avoiding the presence of the disease.

In this way, regarding the attention of the patients, in the current systems of health, there are three levels of attention to be considered in an orderly and stratified manner to organize the resources, in addition to satisfying the needs of the population. Based on Vignolo, Vacarezza, Álvarez, \& Sosa, (2011) are the following:

- The first level is the closest to the population, other means that it is the first level of contact. It is damaged, as a consequence, like the organization of resources enable to solve the necessities of the basic attention and the most frequent too, which can be resolved for those activities of promoting health, preventing diseases, and the procedures of recovering and rehabilitation.

- The second level of attention is placed at the hospitals and establishments where there are services related to the attention in internal medicine, pediatrics, obstetrics-gynecology, general surgery, and psychiatry.

- The third level of attention is the one that supplies attention to problems less prevalent. It concerns the attention of complex pathologies that require specialized procedures of high technology, in which the area of coverage must be the total of a country or the most of it.

Although, these levels do not include the procedures that must be prioritized before having exposure to levels that intend to integrate the Health of Education, even though it seems that takes place in the first level, the relevance to emphasis that is being given is little meaningful or less relevant, since, frequently they refer to small talks, in general without having an impact on the population.

\section{ANALYSIS}

On the basis of the aforementioned, nowadays, when we talk about prevention, that means that we are in the potential or real presence of one or more diseases. In terms of secondary or tertiary attention, the focus is towards the attention of the diseases developed in the person, which represents a high cost not only for the health and the economy of the patients, but also for the family, community, and social economy.

In this way, it is necessary to understand that the physical, mental or social disease develops when there is a loss of balance between body, mind, and/or environment, which even in the initial stages, will always cause permanent and severe effects from major to minor details, not only for the people but also in the context.
Then, the proposal would be to turn the look towards the concept of Health of Education, considering fulfilling the definition proposed by the WHO (2006), to achieve this comprehensive welfare in terms of both the physical aspect and the mental social ones of the people. As a consequence, health personnel, and not disease workers must change, as well as our objectives to do the professional activity, encouraging the Health of Education as an essential and basic objective in the professional activity.

Although it is said that human beings are not born with an "operating manual", I will allow myself to refute this concept since the body has its alarm and warning systems to show that it is losing balance, among which are pain, emotional discomfort, and sadness; however, these are silenced by painkillers, alcohol or other drugs, licit or illicit, as well as with technologies and mass media.

This could be compared to if when there is a fire alarm, instead of going to see what is happening, we would take a stone and silence the alarm so that it would not bother us, causing the fire not to be extinguished and the destruction caused by the fire would be greater and even result in the destruction of the place. All the same, the human body possesses an immunologic system, that without conscious intervention of our part, defends us from external attacks, and looks reestablish the homeostasis, but unfortunately, if the lifestyle of a person includes habits and components that implicate an incidence that is potentially negative for his/her health, the disease caused by external pathogens, wins the battle and deteriorates his/her body.

Thus, although the decline of certain functions and physiological components of the body is natural for all living beings, and normal over time, this process is accelerated by incorrect and even risky lifestyles.

Concerning the potentially negative characteristics of today's society, the dehumanization in the treatment of individuals and the tendency to immediate gratification, without considering the long-term implications, have led to an excessive increase in physical, mental, and social illnesses.

Therefore, I would like to call on professionals in all areas of health care, for example, physicians, psychologists, dentists, and nurses, among others, to reflect and conceptualize the human being, in their professional practice, not as a being that degrades day by day but, on the contrary, as that being that renews itself cellularly every day and that has impressive potential.

Thus, we must update ourselves, study, and inquire about how we can guide and encourage this wonder called "human being" to be able to reach fullness and balance in all senses and, thus, to maintain integral health. In such a way that, both in our training and in our updating, we must integrate elements related to our role as agents who actively participate in education for the maintenance of the health of individuals (Panamerican Health Organization and World Health Organization, 2005). 
The work as a multidisciplinary team, rather than interdisciplinary, is imminently necessary to reach the understanding of the proper functioning of the interrelation and co-dependence of body and mind. Taking this into account, it is necessary to leave aside what can be considered as "false feelings of pride" and preconceptions that segment the human being, to achieve the ultimate goal of health workers, which is the "Healthy Human Being".

In terms of a metaphor, the work in a car factory can be visualized, where the different workers do not know what the others are doing, that is, each technician works individually, without sharing progress, objectives, resources, processes, and strategies, with the sole objective of achieving an economic or personal gain. Honestly, I cannot imagine what kind of car could be obtained and, finally, beyond the shortcomings of aesthetics, if it would be a functional or viable product.

Besides, the impressive amount of controversial information, with unscientific and questionable bases, frequently distorted or manipulated, that people receive daily from unreliable sources, makes people distrust a serious and scientific study. Thus, for example, "health charlatans" promise "magic" remedies that will induce the conditions for a perfect body or eternal happiness, from one day to the next.

And it is at this point that our role as health professionals places us in the position of rethinking our practice, for the integral well-being of the people we promised to help and support.

Hence, Health Education implies several steps to be followed, since it involves a multidisciplinary team, the people who receive the intervention, and the society in which they are inserted. Because, as mentioned by Riquelme, the purpose of it would be to "facilitate people to mobilize their resources and develop skills that allow them to make conscious and autonomous decisions about their own health" (2012, p. 77).

As stated above, it could be considered somewhat utopian or difficult to achieve, it is necessary to present it as an alternative that ethically could be more effective than the traditional practice that has been carried out up to now.

Similarly, advances in technology and the means of production, as well as the ways of life, work, and leisure affect health, so that diseases that were not so prevalent before, such as morbid obesity and its consequences on the health of the population, are appearing.

Likewise, with the use of new technologies, there has been an alarming increase in isolation and little social and family interaction, which has increased suicides and anxiety in general.

Nonetheless, the use of new technologies should also provide elements that strengthen the integral welfare of individuals. In addition to, ensuring that production processes are optimized, leaving human beings time for leisure and coexistence in society.

It is relevant to clarify that the purpose is not to judge technological advances and the means of production as the guilty people, if it is possible to raise awareness as to what improvements, it could be made to promote healthy work, family, and community environments, as well as to use technology and the speed of communications today as a means to promote healthier lifestyles in people.

Another aspect to consider is to promote community action, which would not leave all the responsibility for health education solely in the hands of health personnel, observing the customs of each place and optimizing the knowledge of health in each region

Thus, at the First WHO World Conference on Health Promotion, held in Ottawa, Canada, in 1986, the following actions were proposed to achieve Public Health:

1. To elaborate a public policy for the promotion of health.

2. To create favorable environments.

3. To strengthen community action for active participation in health issues.

4. To develop personal and social skills for selfpreservation of health.

5. To reorient health services with a focus on health promotion.

In consequence, the work should be carried out not only by health professionals but also by governments, communities, and society in general.

Even though, it is important to mention that this dissertation does not intend to politicize or to impact the functioning of health services since these actions are the responsibility of health representatives immersed in politics.

Health professionals are referred to as all those professionals involved in supporting patients who require it, emphasizing that it must be a joint work, in which the person is conceived as an integrated whole, who can not be treated partially and requires multidisciplinary work, that involves more than just attenuating a "symptom", getting to the root cause and helping people to preserve and/or restore a state of integral health.

Based upon the foregoing, the commitment implies that health workers must go beyond the daily practice. For instance, updating ourselves, studying different currents, working in professional associations, and with a diversity of currents, including, knowing and studying traditional medicine. Moreover, the uses and customs of the communities in which individuals live.

Although, on several occasions, it is considered that these actions imply a huge amount of work, the benefit derived from this cost, in the long term, would be much less.If we consider that the treatments involved in diseases, mainly chronic noncommunicable metabolic diseases, would be reduced.

Since the beginning of the last century, Kurt Lewin, father of social psychology, mentioned that behavior was produced by the interaction between individuals and their environment. His work had a great impact on group dynamics techniques and this contribution gave rise to the Field Theory, which was considered in the development of organizations and the business world. 
According to his theory, in the environment in which the individual or group is located, both forces are determinants for the development of a phenomenon (Chiavenato, 2009). Consequently, to achieve a successful change which is being addressed in this document, this model proposes that all the influences received, both individually and from the environment, should be considered through a holistic view of the situation to analyze the interactions.

This is where it becomes evident to make people aware that their destiny depends on their interactions with others so that group actions involve a shared responsibility, particularly concerning their health. Since it is very important to take up these considerations to promote individual progress that will eventually lead to collective wellbeing.

This is where it becomes evident to make people aware that their destiny depends on their interactions with others so that group actions involve a shared responsibility, particularly for their health. Since it is very important to take up these considerations to promote individual progress that will eventually lead to collective wellbeing.

Subsequently, to the Field Theory, a formal discipline based on project evaluation was developed, highlighting those known as rational choice theories, whose outstanding theorists were Anthony Downs and Mancur Olson (Guízar, 2013). From these choices, two aspects that would help us to make decisions are analyzed: cost and benefit, which I will explain graphically below:

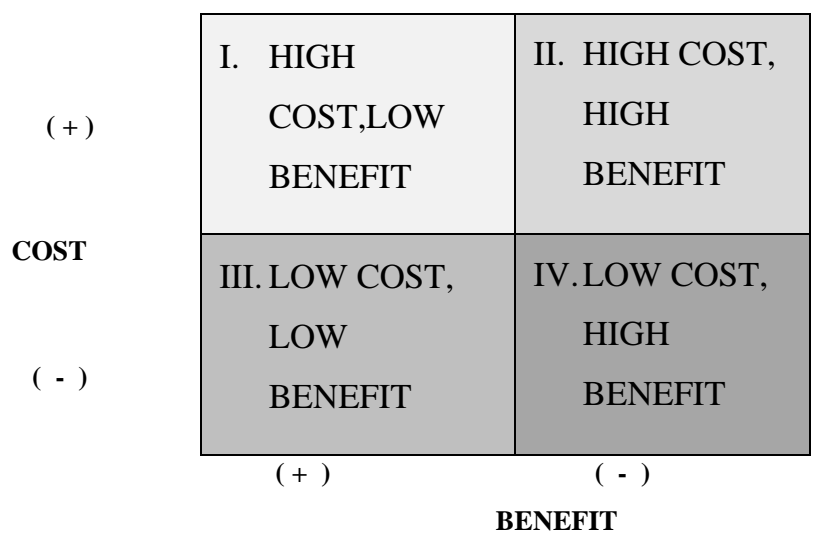

Chart 1. Decision-making based on the cost-benefit.

On the subject under discussion, regarding health and the measures we can adopt to procure it, this table provides us with a vision of how certain decisions may be less indicated according to the possibilities we have and the benefits we obtain.

\section{I.- HIGH COST-LOW BENEFIT.}

A group of children is provided with expensive and controlled drugs for a semester, and their progress is monitored by a doctor and a nurse. In this case, it requires high funding, the willingness and consent of parents or guardians, and very accurate testing methods. Some positive changes may occur, but these are unlikely to prevail once the program is completed.

\section{II.- HIGH COST-HIGH BENEFIT.}

A program of balanced nutrition to be provided in the school, along with physical conditioning for the children, in addition to specific instruction in nutrition and physical activation, by a professional team. This program would be very effective and with great benefits, but it could only be applied in places where there will be adequate conditions and a large amount of funding to carry it out; with which, perhaps, we would be privileging only the upper social classes.

\section{III.- LOW COST-LOW BENEFIT.}

The school conducts physical reactivation classes with its teachers and parents are invited to informative meetings on health improvement. These types of programs are constantly implemented in schools, but the results are not very convincing and have not contributed to the solution of the problem.

\section{IV.- LOW COST-HIGH BENEFIT.}

At this point, we come to Health Education, where it is not a question of seeing a symptom (obesity is a symptom of an inadequate lifestyle), but to address the problem from its origins, creating programs that cover the whole society, forcing the representatives of the countries to turn to see the need for the incidence of changes in habits, rather than only policies or programs that tend to become palliative.

In other words, as stated by the WHO (2021), the purpose is for individuals to reduce the consumption of sugars and saturated fats while increasing the consumption of fruits, vegetables, legumes, and cereals, accompanied by greater regular physical activity. In addition, in parallel, the industrial and commercial sector should reduce the content, both in production and marketing, of saturated fats, refined sugars, and salt, increasing the availability and accessibility of healthier consumption options.

Finally, it is not possible to summarize all the work that this education requires and, of course, the commitment of all the entities involved, but, the main objective is to turn to "the other side of the coin" and consider Health Education as a more ethical, viable, sustainable and adequate model to follow, as an alternative to traditional treatment and interventions.

\section{REFERENCES}

Ardila, C. (2015). Traditional Chinese Medicine in disease prevention, Universidad Man holistica uela Beltrán. Revista Ciencias de la Salud, 13(2), 281-295. https://www.redalyc.org/pdf/562/56238625014.pdf century.

Chiavenato, I. (2009). Organizational behavior. (2 Ed.). Mc-Graw Hill.

Guízar, R. (2013). Organizational development, principles, and applications, fourth edition. Mexico: Mc Graw Hill education. 
Panamerican Health Organization / World Health Organization. (2005).

The Renewal of Primary Health Care in the Pan American Health Organization/World Health Organization (PAHO/WHO) Position Paper. Panamerican Health Organization. http://www.bvsde.paho.org/bvsacd/cd65/RenovacionSalud.pdf.

Reyes, G. \& Ariel, E. (2008). Historical Evolution of Traditional Chinese Medicine. Community and Health, 6(2), 42-49 http://ve.scielo.org/scielo.php?script=sci_arttext\&pid=S1690$32932008000200005 \& \operatorname{lng}=e s \& t \ln g=e s$.

Riquelme, M. (2012). Health education methodology. Rev Pediatr Aten Primaria, 14(22), 77

http://scielo.isciii.es/scielo.php?script=sci_arttext\&pid=S113976322012000200011\&lng=es. https://dx.doi.org/10.4321/S113976322012000200011

Vignolo, J., Vacarezza, M., Alvarez, C., \& Sosa, A. (2011). Levels of care, prevention, and primary health care. Archives of Internal Medicine, $\quad 33(1), \quad 7-11$. http://www.scielo.edu.uy/scielo.php?script=sci_arttext\&pid=S16 88-423X2011000100003\&lng=es\&tlng=es.

World Health Organization (1986). Ottawa Charter for Health Promotion https://www.paho.org/hq/dmdocuments/2013/Carta-de-ottawapara-la-apromocion-de-la-salud-1986-SP.pdf.

World Health Organization. (2006). Constitution of the World Health Organization.

http://www.who.int/governance/eb/who_constitution_sp.pdf.

World Health Organization. (2021). Obesity and overweight. World Health Organization. https://www.who.int/es/news-room/factsheets/detail/obesity-and-overweight. 